\title{
A Flourishing Fintech Ecosystem: Conceptualization and Governing Issues in Malaysia
}

\author{
Sharina Tajul Urus \\ Faculty of Accountancy, Universiti Teknologi MARA \\ Kampus Puncak Alam, Selangor, Malaysia \\ E-mail: sharina675@uitm.edu.my
}

Intan Salwani Mohamed (Corresponding author)

Accounting Research Institute, Universiti Teknologi MARA, Shah Alam, Selangor, Malaysia E-mail: intan838@uitm.edu.my

Received: July 5, 2021 Accepted: August 24, 2021 Published: September 6, 2021

doi:10.5296/ber.v11i3.18729 URL: https://doi.org/10.5296/ber.v11i3.18729

\begin{abstract}
Transforming business transactions from the old "bricks and mortar" physical transaction to "click and order" via digital devices gave birth to financial technology or Fintech. Fintech has arguably democratized financial services, allowing non-traditional firms to enter the space. Fintech refers to digital technologies that integrate various forms of technology, including Blockchain, Robo-advisors, Crowdfunding, Big Data, Peer-to-peer (P2P) lending and intelligent investment consulting in the financial sector. Nonetheless, the Fintech research topic in developing countries like Malaysia is still at the nascent stage. The previous literature has recognized the Fintech evolvement, features, and effect but has not yet provided a comprehensive conceptualization and manifestation. The governing issues of Fintech are also still worth further investigation. Based on the fintech literature review, this paper explores the Fintech conceptualization and its governing issues in-depth. The study will contribute to understanding Fintech, its manifestation, and how Fintech evolves. This concept paper also shed some light on Fintech research areas by identifying the governing issues surrounding Fintech implementation. From the practical perspective, the contribution is a recommendation on how the Fintech application could be utilized optimally by the Fintech companies that would positively impact the Malaysia ecosystem and contribute to the national agenda.
\end{abstract}

Keywords: Financial technology (Fintech), Fintech conceptualization, Fintech manifestation, 
Fintech governing issues, Fintech companies

\section{Introduction}

The fourth industrial revolution (IR4.0) has unfurled its wings over all industries; consequently, its positive impact on the modern global economy has emerged significantly. The financial services sector is also one of the sectors that have leveraged the power of Industry 4.0. via the introduction of Financial Technologies (Fintech). The application of technology in financial transactions provide more innovative ways on how to conduct business. Fintech creates the possibility that financial services offered by traditional banking providers such as money transfer, lending, investment, or payment can be done cheaper and more conveniently. Fintech also allows the company's operation to be more automated, lowers cost information acquisition, and makes manufacturing and distribution processes more efficient (Gupta \& Tham, 2019). Financial technology or, in simple terms, "Fintech" comes from the combination of finances and technology, implying the implementation of innovative technologies such as smartphones and the Internet in improving financial services productivity and efficiency without the intermediary of the financial institution (Chuang et al., 2016).

Fintech, which constitutes a key player in the fourth industrial revolution, amalgamates finance and technology (Chang et al., 2020; Lee \& Shin, 2018) and encompasses platforms such as mobile payments, peer-to-peer lending, and robotic investment advice (Schueffel, 2016). Rupeika-Apoga \& Thalassinos (2020) postulated that Fintech refers to the advancement in technology that can transform the distribution of financial services spurring the development of new business models, applications, processes, and products. Fintech also refers to a new technology that seeks to improve and automate the delivery and use of financial services.

The introduction and continuous development of Fintech have had a positive impact on the financial sector. For example, Fintech companies have developed a new approach for payment services, namely mobile wallet (e-wallet), which aims to simplify the transaction process and improve customer services (Kang, 2018). The convenience factors of Fintech become one of the more vital determinants to influence the adoption of Fintech among users, whereby they can use financial-based services easily anytime and at any place. The convenience provided by the system eventually increases the users' performance as many transactions can be performed remotely, which increase the adoption of the technology (Putritama, 2019).

Undoubtedly, the Fintech industry will continue to grow due to innovations in the information and internet age. The previous literature has recognized the fintech evolvement, features, and effect it brings. For instance, Knewtson \& Rosenbaum (2020) asserted that the use of the term "Fintech" has grown twenty-five-fold over the past decade and with the emergence of new Fintech firms, over 1,000,000 jobs are linked to Fintech. Any technology-focused firms that employ innovations like Fintech will disrupt the establishment of traditional financial services yet strive to revolutionize and reshape the financial ecosystem (Arslanian \& Fischer, 2019). However, they believed it is not an easy road as the actual situation for Fintech development is far more complex to understand (Arslanian \& Fischer, 2019). 
Additionally, despite its tremendous development, the Fintech research topic in a developing country is still nascent. Cheah et al. (2011) indicated that numerous studies on Fintech payment adoption in developed countries such as Singapore, Korea, Brazil, China, and Taiwan comparatively slightly paid attention to developing countries such as Malaysia. Fintech's application to Malaysians is still developing, and it is relatively foreign. Hence, findings from developing countries such as Malaysia remain to be interesting. The previous literature has recognized the Fintech evolvement, features, and affect but has not yet provided a comprehensive conceptualization and manifestation. The governing issues of Fintech are also still worth further investigation since Fintech initiatives have also encompassed some problems such as potential fraud, excessive pressure to meet targets and untried business models, and exposures to fraud (Nicoletti, 2017). Companies and financial institutions need to face any obstacles occurring in this industry to embrace Fintech. Learning from mistakes and turning threats into opportunities is one of many ways to survive the "Fintech wave" (Deloitte, 2020). Hence, the paper aims to explore the Fintech conceptualization and governing issues based on reviewing the Fintech literature.

The study will contribute to understanding Fintech, its manifestation, and how Fintech evolves. This concept paper also shed some light on Fintech research areas by identifying the governing issues surrounding Fintech implementation. From the practical perspective, the contribution in the form of recommendation on how Fintech application could be utilized optimally by the Fintech companies would positively impact the Malaysia ecosystem and contribute to the national agenda.

\section{Fintech Conceptualization}

\subsection{What is Fintech - Fintech Definition}

The history of financial transactions has evolved from the barter system to physical money to a cashless system for thousands of years. In modern days, technology plays a vital role in innovating how we use our money and asset. The merging of modern technology within financial transactions gives a rise towards 'fintech'. In simple words, Fintech can be understood as a new financial industry that employs technology to improve economic activities (Schueffel, 2017). These activities include payments, lending, wealth management and insurance space (Arjunwadkar, 2018). Fintech also can be understood as financial innovations that use technological solutions in different business situations and lead to new business models or even new businesses (Di Pietro et al., 2021).

\subsection{Fintech Dimension}

Fintech covers various transactions, including insurance technology, financial data, payment and banking systems and mobile banking, where payment services are the largest subcategory being covered under Fintech (Szakiel, 2018). Fintech payment services have improved the way that people are dealing with business. The tools provided by Fintech enables the consumers to track, manage and facilitate their finances remotely. Das (2019) suggests that the use of Fintech in finance brought a change in three areas: (a) raising capital, (b) allocating capital, and (c) transferring capital. Thus, we could say that almost all modern business 
transactions revolve around the use of Fintech.

Due to its broad classification mechanisms of Fintech, O'Hanlon et al. (2020) recommended the three dimensions of Fintech, which consists of (1) financial sector, (2) business model, and (3) technology. Figure 1 below illustrates the 'Fintech cube' based on these three dimensions.

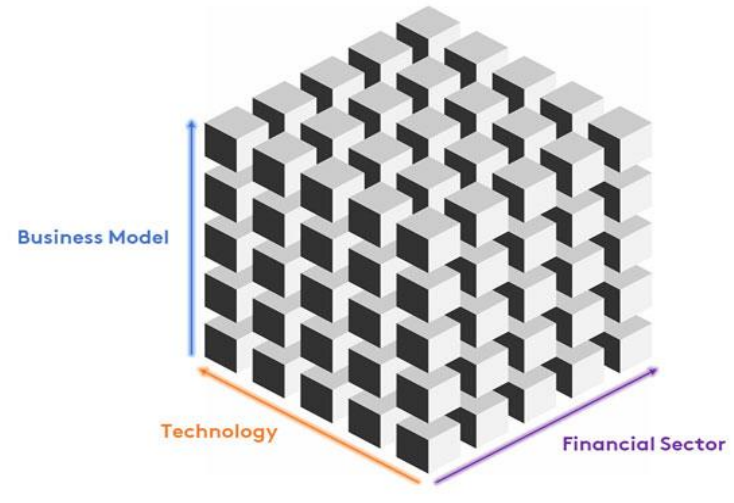

Figure 1. The Fintech Cube by O'Hanlon et al. (2020)

The Financial sector dimension outlines the critical areas in the financial services that will benefit from using Fintech. It includes banking, stock trading, asset management, transaction payments, insurance, foreign exchange, and others. The business model explains different important types of models used by the company to conduct their business which include business-to-consumer (B2C), business-to-business (B2B), business-to-business-to-consumer (B2B2C), to business-to-government/regulator (B2G), to platform-based business models, crowdfunding, and peer-to-peer (P2P) lending. Lastly, the technology dimensions indicate different types of technology use within the business. It includes cloud computing, big data, artificial intelligence (AI)/machine learning (ML), Blockchain (distributed ledger technologies), the Internet of Things (IoT), and quantum computing, to augmented and virtual reality.

\subsection{Fintech Application}

Fintech payment services have improved the way that people are dealing with business. The tools provided by Fintech enable the consumers to track, manage and facilitate their finances remotely. Fintech refers to companies that provide financial services, primarily focusing on the technology platform for innovative financial services products. It is not limited to specific areas (e.g., financing) or business models. Still, it covers various high-tech systems in financial industries like mobile payments, loans, financing, money transfers, and even asset management (Arner et al., 2015). Arner et al. (2015) further suggested the differences between traditional financial services and Fintech, where it is not a mere combination of information technology and financial services, but the implementation of technology into traditional services to expand their context. Fintech covers various transactions, including insurance technology, financial data, payment and banking systems, and mobile banking, 


\section{Macrothink}

Business and Economic Research

ISSN 2162-4860 2021, Vol. 11, No. 3

where payment services are the largest subcategory being covered under Fintech (Szakiel, 2018).

The following diagram (figure 2) illustrates some of the Fintech applications currently available to serve various purposes in daily activities.

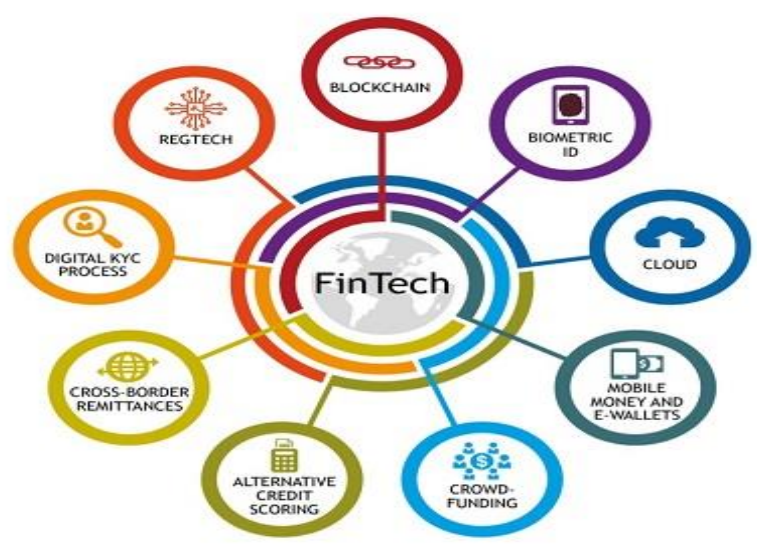

Figure 2. Fintech Application (Alliance for Financial Inclusion, 2018)

Table 1 below shows the snapshot of some of the Fintech Applications that are currently available. Amongst include Crowdfunding, Mobile payment, Robo-Advisor and Insuretch. 
Table 1. Snapshot of Fintech Application

\begin{tabular}{|c|c|c|}
\hline $\begin{array}{l}\text { Application of } \\
\text { Fintech }\end{array}$ & Example & Usage \\
\hline $\begin{array}{l}\text { Crowdfunding } \\
\text { Platforms }\end{array}$ & $\begin{array}{l}\text { - } \text { GoFundMe } \\
\text { - } \quad \text { Patreon } \\
\text { - } \quad \text { Chuffed } \\
\text { - } \quad \text { Community } \\
\text { Funded }\end{array}$ & $\begin{array}{l}\text { Enable entrepreneurs to collect the funds worldwide and } \\
\text { transmit them to any country (i.e., international markets and } \\
\text { investors). } \\
\text { For example - Chuffed The platform for charities and } \\
\text { non-profit organizations. They are used for social campaigns } \\
\text { worldwide, promotion activities and monitoring donor participation } \\
\text { that support the organization. }\end{array}$ \\
\hline Mobile Payment & $\begin{array}{ll}\text { - } & \text { Stripe } \\
\text { - } & \text { Maybank } 2 \mathrm{U} \\
\text { - } & \text { Paypal }\end{array}$ & $\begin{array}{l}\text { It allows the user to make a daily transaction or any banking } \\
\text { activities, credit services and transfer money online on any device } \\
\text { without going to the bank. } \\
\text { For example, Maybank2U enables a user to make a payment for } \\
\text { online shopping. }\end{array}$ \\
\hline Robo-Advisors & $\begin{array}{l}\text { - Betterment } \\
\text { and Ellevest } \\
\text { - Charles } \\
\text { Schwab }\end{array}$ & $\begin{array}{l}\text { It allows the user in making investment activities with minimal } \\
\text { effort and lowers fees. } \\
\text { Provides algorithm-based asset recommendations and portfolio } \\
\text { management that may increase investment efficiency with cost } \\
\text { reduction. }\end{array}$ \\
\hline Insuretech & $\begin{array}{ll}\text { - } & \text { Lazarus AI } \\
\text { - } & \text { Relay } \\
\text { - } & \text { Halos } \\
\text { - } & \text { Oscar Health }\end{array}$ & $\begin{array}{l}\text { Allows the companies to provide tailored insurance services } \\
\text { and data security. } \\
\text { policy management and offer the claim service to the insurance } \\
\text { company's client. }\end{array}$ \\
\hline
\end{tabular}

\subsection{Fintech Benefits and Challenges}

Fintech has become essential for financial development, social stability and integrity, and significant effect in constructing infrastructure for an innovative digital financial ecosystem (Zhang-Zhang et al., 2020). Razzaque \& Hamdan (2020) highlighted a few key benefits of Fintech, such as more economical, seamless transaction, and convenience. With Fintech, consumers can instantly pay their bills from home comfort and do all kinds of financial transactions. Fintech also helps businesses to manage a massive amount of data efficiently and effectively. For example, the emergence of the Internet of things and big data analysis enables companies to collect enormous data from their consumers. It generates value by determining the key information needed (Nicoletti, 2017). These data help businesses provide the best services or goods suitable for each consumer's preferences (Imerman \& Fabozzi, 2020).

In recent years, financial transactions have experienced many significant changes in consumer payment, with most countries beginning to move to cashless transactions (Desai, 2015). Debit cards or credit cards are one of the most famous traditional methods of payment 
for cashless transactions. From the point of view of many consumers, payment by credit cards will ease them through mobile wallet (e-wallet), which aims to simplify the transaction process and improve customer services (Kang, 2018). The convenience factor derived from the fintech system eventually increases the users' performance as many transactions can be performed remotely, expanding the technology's adoption (Putritama, 2019). The intermediaries, such as banks or other financial institutions, are no longer required with Fintech payment services as users can independently manage their finances (Putritama, 2019). Bank or other financial institutions are usually associated with an additional charge for their services. Therefore, Fintech allows cost reduction to the users. Fintech also provides a seamless transaction to the users. It is a key feature of Fintech transactions that replaces traditional financial institutions in terms of the financing process and allows users to manage their transactions on fast, simple, and cheap financial transactions (Zavolokina et al., 2016).

When there is a rapid evolution of technology, it is usually accompanied by increased cyber-attack threats. Cyber-attacks on mobile banking apps and wireless network operating systems remain a significant data security issue. Such attacks have created a high degree of mistrust of online payment transactions due to the increased risk of unauthorized transactions done by unauthorized persons (Stewart \& Jürjens, 2018). Consumers care about their data privacy, and the problem arises when their data are accessed by an unauthorized individual or leaked to third-party companies. It is the main issue involving online monetary transactions, where without proper security, the system could bring substantial financial damages to the user (Kang, 2018).

\section{Evolvement and Development of Fintech}

\subsection{Fintech Evolvement Worldwide}

Mohamed \& Ali (2019) divide Fintech evolution into three stages. First, Fintech 1.0 lasted from 1866 to 1987 . During this period, the first industrial revolution gave birth to many valuable technologies such as the telegraph, transatlantic cable, steamships, and railroads to improve the speed of financial transactions and extend their reach globally. In the mid- $20^{\text {th }}$ century, the introduction of the electronic system increases the automation of financial transactions (Buckley et al., 2016). Now cash can be withdrawn using an automated teller machine (ATM) without going to banks; stocks are traded using desktop terminals, and payments can be made easily using credit cards.

Fintech 2.0 started from 1987 to 2008 at the dawning age of digitalization. The increased size of information connectivity may help speed up information sharing among intermediaries. Still, it is also caught the attention of regulators to regulate the market and ensure no laws were broken (Puschmann, 2017). Nevertheless, internet technology raised many Fintech innovations, including digital banking and online payments such as PayPal and others. Such innovations can disrupt the existing industry structure, reduce the industry boundaries, change how services and products are delivered, and provide new channels for entrepreneurship and financial services (Wang et al., 2021).

Fintech 3.0 emerge after the 2008 global financial crisis to the present day. The distrust 
towards the traditional banking system and loss of jobs by financial professionals gave rise to new fintech innovations (Arner et al., 2017). During this stage, cryptocurrency or digital money becomes more and more common as it becomes more affordable and regularly used by the public (Mohamed \& Ali, 2019). In a recent development, Fintech has become a common buzzword since it is happening all around us. From buying our everyday needs online to trading in the stock market. The global investment into Fintech is expected to grow tremendously align with the growth of the consumers' and investors' optimism (FINTECH Circle Institute, 2020). In 2018, it was reported that the global investment in Fintech amounted to USD 111.8 billion (Ryu \& Ko, 2020). For instance, PwC (2019) believed that the most popular Fintech technology being discussed is artificial intelligence (AI). AI uses applications and techniques such as natural language processing, deep learning, reinforcement learning to enhance services provided to consumers and business partners and drive new product design (Qi \& Xiao, 2018). With continuous developments, the Fintech industry is expected to experience a disruptive transformation that could lead to positive and negative consequences (Deshpande, 2020).

The following diagram (figure 3) shows the evolvement of Fintech over time.

$\begin{array}{lll}\text { GEOCRAPHY } & \begin{array}{l}\text { Clobal/ } \\ \text { Developed }\end{array} \\ \text { KEY ELE. } \\ \text { MENTS }\end{array}$

Figure 3. Fintech Timeline for the year 1866-2020 (Zigurat Global Institute of Technology, 2020)

\subsection{Fintech in the Pandemic Era (Covid-19)}

The year 2020 has become one of the most highlighted years in the past decades due to the 2019 novel coronavirus (COVID-19). People are now being quarantined in their homes to prevent the further spread of the virus. The restriction of movement disrupts how people go on with their daily lives, negatively impacting the overall economic environment. COVID-19 has negatively affected the world's economies, causing a global health crisis and impair international trade and commerce (Aktar et al., 2021). Jackson et al. (2021) reported that this pandemic had reduced the annual global economic growth by $-4.5 \%$ to $-6 \%$ in 2020 . They also added that the unemployment rate has risen to a level not experienced since the Great 
Depression in the 1930s.

However, in a Fintech environment, the situation is different. World Bank and World Economic Forum (2020) stated that Fintech transactions have risen in numbers and volumes of $13 \%$ and $11 \%$, respectively, in the first and second quarters of 2020 . One reason for this increase is that the pandemic environment pushes companies to rely on online services to provide their products ( $\mathrm{Li}$ et al., 2020). This pandemic offers many opportunities for Fintech to grow. Mansour (2021) stated that Fintech also extends the consumer's reach during the lockdown using the cashless system. It enables financial transactions to be done with as minimal physical contact as possible.

\subsection{Fintech in Malaysia}

From the Malaysian perspective, the fintech development in the country is quite encouraging. The emergence of Fintech in Malaysia has altered the country's financial sector landscape. Although Fintech is considered a new phenomenon in Malaysia, many Fintech startup companies have started to emerge due to increased interest from the general public (Razak et al., 2020; Baber, 2020; Cham et al., 2018; Chan et al., 2020). The rise of Fintech in Malaysia, such as online banking and electronic payments, has increased the competitiveness of technology usage. Institutions offer services that challenge and react to consumers' attitudes towards new technology products to gain market opportunities (Chong et al., 2019). Additionally, while Fintech products offered by traditional financial institutions expand, the number of physical commercial bank branches is declining, and the number of automated teller machines has fallen over since 2018 in Malaysia (IMF Report, 2020). Traditional Malaysian banks continue to dominate in deposits, lending, and raising capital, yet, at the same time, these Financial Institutions also adopt new technologies, either competing or collaborating with the latest technology startups. IMF (2020) also reported that as of April 2019, there were close to 200 startups in Malaysia in a range of Fintech areas, including payments, lending, and blockchain.

This escalating trend resume from 2020 onwards was instigated by a pandemic that has accelerated digital banking adoption. Based on the recent report by Fintech News Malaysia (2021), the online and mobile banking penetration reached $112.5 \%$ and $61.8 \%$, respectively, and RM 460 million worth of mobile banking transactions were conducted indicated a $25 \%$ jump as compared to 2019. The Malaysian government's Movement Control Order (MCO) acted as a catalyst to increase the 3 million new mobile banking service contributors. This incremental trend also has increased e-wallet usage and adoption. The growing pace is also evidenced by the emergence of more than 400,000 new businesses registered for the employment of the QR code for payment purposes, a rise of $164 \%$ jump from 2019.

Malaysian governmental bodies also have launched many campaigns to encourage the use of new types of Fintech. The Malaysian government has also taken some initiatives to promote the use of Fintech. For instance, the Malaysian government has announced RM750 million allocation to promote Fintech payment services adoption in Malaysia (Fong, 2020). Fong further suggested from the plan, RM50 was credited to approximately 15 million Malaysians' e-wallet accounts in July 2020. Additionally, The Malaysia Digital Economy Corporation 
(MDEC) recently has launched the "Fintech Booster" program, which helps companies to understand the overall scope of Fintech and its legal, compliance and regulation requirements (Malaysia Digital Economy Corporation, 2020). MDEC also has created a vibrant Financial Technology (Fintech) ecosystem and leveraging the expertise and knowledge in Islamic Finance. It is consistent as Malaysia is ranked 32nd out of 121 (the best-performing country), leading the group of upper-middle-income countries (Dutta et al., 2019). The framework evidenced that the Malaysian government had a significant investment in the procurement of advanced technologies. These strategies are employed to promote Malaysia to become a developed country in line with other developed countries such as Singapore, United States and Japan. Hence, it is crucial for everyone in Malaysia to take the first step to adopt this technology to boost the Malaysian economy.

For instance, Bank Negara Malaysia (BNM) is committed to boosting the local Fintech industry by providing a conducive regulatory environment called 'Fintech regulatory sandbox' to deploy Fintech. It enables the experimentation of Fintech solutions in a controlled environment (Bank Negara Malaysia, 2016); this country has become the world's top destination for Islamic finance (Rabbani et al., 2020; Shaikh et al., 2020). Thus, the use of Fintech in Islamic finance has also increased. A few examples that can be observed are Robo-advisory services for Islamic banks, including Chatbot for financial advice and AI-based Zakat calculation (Hassan et al., 2020). From these trends, it is expected for the Fintech industry to continually grows in the Malaysian environment.

The development of Fintech in Malaysia, such as electronic payments and online banking, has contributed to the increasing advancement in technology productivity in Malaysia. The services offered by the financial institutions continue to challenge and cater to the attitudes of consumers who accept new technology products to gain market opportunities. Financial institutions have significant market potential to maintain market share in response to the latest technology, recent changes, and millennium generations involving new technology applications. Thus, according to Ryu (2018), Fintech has become an important and interesting topic given the rapid growth and information technology changes. The most popular services in Malaysia are digital payments and mobile wallets, with many local Fintech enthusiasts working hard to expand their portfolio and create unique products for local consumption (Rabin, 2020). The following are some of the key trends taken place across Malaysia relating to Fintech:

(1) Peer-to-peer (P2P) financing and equity crowdfunding (ECF)

Peer to peer lending is a platform that enables individuals to lend money without using financial institutions as an intermediary. It is a relatively new concept in Malaysia. Security Commission (CS) has introduced the regulatory framework for P2P under the Guidelines on Recognized Markets under section 377 of the Capital Markets and Services Act 2007 (CMSA). Currently, there are 11 registered Recognized Market Operator (RMO) which operates in Peer-to-peer financing in Malaysia (Dinniya, Aulia \& Wahyudi, 2021). 
The introduction of P2P and ECF enables fund-raising from individuals or retail investors via an internet platform without an intermediary such as a bank and funding or investment by investors in exchange for shares in startup entrepreneurs and small and medium enterprises. SC has, in the year 2016, approved six P2P operators, namely B2B FinPAL, Kapital, FundedByMe Malaysia, ManagePay Services, Modalku Ventures and Peoplender, as well as six ECF providers, namely FundedByMe (Alix Global), Ata Plus, Crowdonomic, Eureeca, pitchIN and CrowdPlus.

(2) Mobile wallet

Mobile e-wallet or digital e-wallet is one of the emerging Financial Technologies (Fintech) that has become highly prevalent during the last few years. Mobile wallet is a technology that needs to be enabled on users' smartphones, allowing the users to store money and perform online transactions directly. As the world is slowly moving away from using cash, contingent on technology for making payments, mobile e-wallet has been one of the proficient instruments. With the growth in technology use and shift to alternative payment methods, mobile e-wallet has been one instrument in use (Alwi et al., 2021). Some of the big Fintech firms that provide payment solutions such as GrabPay, Touch n Go (a partnership with Ant Financial), and WeChat Pay are among the most popular providers in Malaysia based on Financial Times Confidential Research (IMF, 2020).

Malaysia's largest financial services providers, such as Maybank and CIMB, aggressively promoting the cashless trend through mobile wallets and other products. Maybank launched Malaysia's first mobile payment platform, MaybankPay, in July 2016, allowing users to tap their smartphones on Visa payWave terminals to make payments, which CIMB Pay followed in December 2016. Both financial Institutions announced that they would also introduce support for Alipay mobile wallet in Malaysia by collaborating with China's Ant Financial Services Group.

(3) Initial Coins Offerings (ICOs)/ Crypto Assets

The Securities commission stated that the framework for crypto exchanges would fall under the Guidelines on Recognized Markets, the same guideline for ECF and P2P lending players. The regulator has amended a specific section to introduce new requirements for crypto exchanges. Under the new guidelines, any person interested in operating is required to register to SC as a recognized market operator in March 1, 2019. The next registration is subject to the review from the SC. The revised guidelines also noted that any person operating unauthorized initial coin offering (ICOs) or digital asset exchange would be subject to 10 years imprisonment and a RM10 Million fine (Dinniya, Aulia \& Wahyudi, 2021).

(4) Fintech development by Malaysia Banks 
Hong Leong Bank has introduced a HLB LaunchPad, a three-month mentorship and developmental program targeted at nurturing the future generation of promising Malaysian technology and Fintech startups, specifically focusing on simplifying banking, digitizing customer journeys and experience, and re-imagining banking services. Maybank also has launched Maybank Sandbox, which provides a complete ecosystem with all the essential components for free to fast-track the growth of Fintech developers across the region.

Despite its popularity and the rising trend of Fintech, the system's governance issues are also considered crucial components. The following section is detailed out in the discussion on the Fintech governance issue, specifically in the Malaysian context.

\section{Governing Issue of Fintech System in Malaysia}

The rise of Fintech in Malaysia also gives rise to several issues and challenges. Knight \& Wójcik (2020) stated that the fintech field is full-on controversies and problems contributing to Fintech research debates. Ryu (2018) noted that some Fintech users are still reluctant to trust the system because it has considerable risks. Some of Fintech usage risks include security/privacy, performance, legal, product, performance, and others. Note that many issues and risks occur in different stages of Fintech life. The following section highlights explicitly a few problems concerning Fintech based on prior literature and trends.

\subsection{Security Issue in Fintech}

Consumer's satisfaction is important for the products or services' continuance use. Fintech services need to be reliable to ensure consumer retention. Maintaining proper security and privacy in Fintech has always been a problem for Fintech companies (Agrawal et al., 2020; Gai et al., 2017). Gai et al. (2018) indicate that financial firms fail to predict and govern the return on investment on security. It has caused them to abandon the effort on strengthening the cybersecurity measures within their firms.

In Fintech, much data is being processed to produce valuable insights that help organizations manage their operation. This data would include sensitive information like employees' information, company's corporate information, and consumer's personal information. In the event of a cyber-attack, fintech companies' data can be compromised by hackers and used to extort a huge amount of money (Ahn \& Cho, 2019). In another example of a data security breach, Cham et al. (2018) explain that one of Fintech's privacy and security risks would include situations where the consumers' personal information was shared among businesses without the owners' consent.

Although companies have been working hard to improve the overall security and safety of Fintech systems, continuous data breach scandals and security issues have led to an increase in scepticism among Fintech users. One example that can be observed is from FacebookCambridge Analytica data scandal in 2018. Pillai (2018) in The Edge Markets reported that around 87 million Facebook users' data were used without their consent for political advertising. The data include the user's public profile, page likes, birthday, and current location. Another infamous cybersecurity incident was eBay's data breach in 2014, where 145 
million active users' personal information was stolen by hackers (Peterson, 2014).

\subsection{Regulatory Issue in Fintech}

As Fintech grows, so does its guidelines and regulatory framework. Rules and regulations are important to maintain industry and mitigate specific risks properly. Arner et al. (2017) stated that the principal regulatory objectives would include financial stability, prudential safety and soundness, consumer protection and market integrity, and market competition and development. The finance industry is one of the most regulated industries since it played a crucial role in the economy (Degerli, 2019). However, since Fintech is relatively new to the Malaysian market, there are insufficient guidelines on Fintech's currency-related incidents and security issues (Ooi et al., 2020). As in 2019, the Fintech environment in Malaysia consists of 198 players that use different types of financial technologies ranging from payments, E-wallets, lending, Insurtech, Crowdfunding, Big Data, Blockchain, Islamic Fintech, and many more (Fintech News Malaysia, 2019). Each of these Fintech fields needs to be monitored by proper authorities to ensure nothing unlawful is done.

Previous literature raises many concerns regarding regulatory issues within Fintech (Bollaert et al., 2021; Degerli, 2019; Omarova, 2020; Suryono et al., 2020). Iman (2020) stated that the various intersection between functionalities, consumers, technological platforms, and emerging business models in rising Fintech firms gave regulators challenges to produce a proper regulatory framework for Fintech. The Fintech environment relies on innovations such as the Internet, which presents a few security hazards. It includes illegal activities such as unlawful tax avoidance, money laundering, terrorist financing, and so forth (Kulkarni \& Lakhe, 2020). The need to regulate the Fintech industry is important to ensure the users of Fintech feels secure and smoothen the operations in the Fintech environment.

Several studies have also discussed how Fintech will affect the Islamic finance sector in Malaysia (Hui et al., 2019; Mohamed, 2020). As Malaysia moving towards becoming the top player in Islamic finance, Islamic financial institutions must ensure that all the financial technologies adopted are in line with sharia compliance. For example, Bitcoin and other cryptocurrencies are non-complying with sharia (Hasan et al., 2020). Whether a specific type of Fintech is permissible by Islam and what new regulation should be added into the Islamic finance framework are many issues the Islamic finance sector faces. The guidelines and rules surrounding Fintech need to be constantly updated and reviewed so that this industry can prosper.

One example of how complicated the Fintech regulatory environment in Malaysia is on the management of Cryptocurrencies. Financial technologies such as cryptocurrencies have been widely used to conduct nefarious transactions in the dark markets (University of Malaya Malaysian Centre of Regulatory Studies, 2018). One popular type of cryptocurrency is Bitcoin. Bank Negara Malaysia (2014) has stated that the central bank does not regulate the operation of Bitcoin and advise the public to be more cautious of the risks associated with this digital currency. Nevertheless, Fintech player in Malaysia such as Luno Malaysia has managed over RM 1 billion worth of digital assets, including 62\% of it from Bitcoin that has been used across this country (Yusof, 2021). 


\subsection{Technology Integration}

Other than security and regulatory issues, there are several issues on Fintech that arise in recent years. Concerning the emergence of new Fintech startup companies, Lee \& Shin (2018) stated that Fintech startups needed to prepare themselves for unprecedented changes that could lead to many challenges. One of the challenges discussed was technology integration between Fintech companies and more traditional financial institutions like banks (Lee \& Shin, 2018; Sloboda \& Demianyk, 2020). Since Fintech is driven by innovation, a new type of financial technology emerges constantly. Vijai (2019), in the study on Fintech usage in India, found that the integration of new technologies such as blockchain and cryptocurrency is still in a niche stage. Similarly, blockchain technology comprises only 7\% of Fintech players (Fintech News Malaysia, 2019). PwC (2019) highlighted that implementing and integrating new financial technologies incur long delays, especially in developing markets. Companies that decided to embrace Fintech may face challenges adapting and integrating to new and different technologies. Compared to banks and more prominent financial institutions, Fintech startup companies face challenges scaling up their business while larger financial institutions may lack the drive to innovate and optimize Fintech services (Acar \& Çitak, 2019; Iman, 2019).

\subsection{Lack of Skill and Knowledge}

Although the Fintech industry is very prestigious worldwide, additional effort and extra push are needed for the local population of young entrepreneurs and developers in Malaysia in investing in the startup scene. Employees in Fintech companies also needed to be skilled, knowledgeable, and well-versed in Fintech technologies. Among the concerns around safety, which are universal, is the lack of talent. The human resources are something that the Malaysian Fintech startup scene is inadequate. Specifically, positions of data analytics, machine learning, and regulatory bodies are often left empty.

The demand for Fintech talent raises the requirement for developing proper education and retraining for existing and potential finance users (Sung et al., 2019). Muthaiyah \& Zaw (2020) stated that some of the "digital soft skills" required for competent employees would include knowledge in blockchain, e-audit, big data, cryptocurrencies, auditing on the cloud, softbot counselling, robotics in business process automation, peer-to-peer transactions, application of artificial intelligence in treasury-related works, and crowdfunding.

In Malaysia, where Islamic Fintech is prevalent, there is a demand for specialists in sharia-compliant finance (Jamil \& Abu Seman, 2019). Studies indicate that the Fintech industry facing challenges regarding the lack of competent skills among employees, particularly in developing countries such as India, Thailand, and Malaysia (Kijkasiwat, 2021; Mei et al., 2018; Vijai, 2019).

\section{Recommendation}

\subsection{Data Protection}

To improve the security and protection of personal and business information, companies 
operating in the Fintech environment need to meet specific standards. Since the Fintech environment is constantly evolving, new security threats and risks are always emerging. There are many ways to improve the cybersecurity measures in the company, depending on how robust it is implemented. Cybersecurity and proper authentication need to be mandatory practices in Fintech companies, but they must be flexible, adaptable, robust, able to trace a wide variety of threats and make intelligent real-time decisions (Blakstad \& Allen, 2018; Moşteanu, 2020). Financial institutions that manage their cybersecurity risks effectively can increase their success rate of defending against cyber-attacks (Mehrban et al., 2020).

Each technology brings its own sets of security risks. For example, O'Hanlon et al. (2020) addressed different security issues revolving around different types of financial technologies, including cloud computing, blockchain, and open source technology. Companies should put more investment towards cyber-securities and incorporating them into the design of Fintech from the very beginning of its life cycle (Miskam et al., 2018). One way to improve the cybersecurity and protection of data is to mitigate cyber-attacks and data breach opportunities (Ng \& Kwok, 2017). It can be done by having proper internal control within the company. Stewart \& Jürjens (2018) added that Fintech companies should start investing more on assets in gathering, examining, and sharing cyber-attack intelligence information better to make sense of the changes in complex security risks.

Moreover, strict security measures and procedures should be implemented to make it less vulnerable (O'Hanlon et al., 2020). This would include:

(1) Employ a comprehensive licensing mechanism.

(2) Create precise requirements around authentication and event logging.

(3) Test every release against clearly defined security standards.

(4) Use multifactor authentication.

(5) Establish clearly defined rules for data encryption.

Concerning data protection, the government, companies, consumers, and other parties need to be proactive and responsible when using any type of financial technology. Fintech companies need to carry out more robust mechanisms for seeking consumer's consent for data sharing and reuse and apply technologies and processes for data life cycle management to ensure data is not abused or exploited in the grey market ( $\mathrm{PwC}, 2016)$. Companies can help protect their own and consumer's data by applying better authentication tools such as digital certificates, mobile device certificates, and biometrics identification ( $\mathrm{Ng} \&$ Kwok, 2017). Other than that, data encryption is also an effective way to protect data from cyber-attacks (Hernández et al., 2019). With proper encryption techniques, companies can protect their data in three stages; when it is in transit, when it is stored, and when the users use it (Varshney et al., 2020).

\subsection{Proper Regulatory Framework}

Next, a proper regulatory framework can help encourage the development of innovations and competition in Fintech companies and improve the overall security of financial technologies (Jagtiani \& John, 2018). Developed countries in the European Union, the United Kingdom, and the United States of America have all acknowledged the importance of Fintech industry 
regulations to protect companies and consumers (Chiu, 2017). Regulators in Malaysia should constantly be up to date with newer technologies and regulatory issues that will arise in the future and consider those issues in developing a new regulatory framework to protect the interest of Fintech companies.

University of Malaya Malaysian Centre of Regulatory Studies (2018) stated that to provide a positive regulatory effect, regulators must follow these objectives:

(1) Regulatory processes must take note of the effects of technical change.

(2) Competition amongst firms should be introduced.

(3) Regulations should be streamlined by removing duplicative, onerous, and inefficient regulations.

(4) A technology-friendly approach should be considered, like economic instruments, voluntary agreements, and performance rather than standards design.

(5) Regulations should be harmonized internationally to remove uncertainties, inefficiencies and market barriers that may slow innovation.

The establishment of the regulatory sandbox in Malaysia is just one of many early initiatives by the BNM to improve this region's overall Fintech regulatory environment. Malaysia's regulators and financial institutions should consider implementing various regulatory technology or "Regtech" to move forward. Regtech can be understood as using innovative technology by supervisory organizations to support regulations and achieve broader analytical scrutiny (Broeders \& Prenio, 2018; Micheler \& Whaley, 2020). Regtech uses similar technologies like Fintech, such as machine learning, low code and artificial intelligence, to help financial institutions meet the challenges of regulatory monitoring, reporting, compliance and risk management while reducing compliance-related costs and allowing a fully compliant experience for their customers (Alam et al., 2019). Regtech can also be useful for sharia regulations in Islamic finance. Hassan et al. (2020) stated that "Islamic Regtech" could help improve transparency, consistency, and standardization of regulatory processes in Islamic finance and is critical to ensure that the advancement of technology in Fintech does not compromise the principles of sharia.

\subsection{Collaboration with Financial Institution}

To promote better growth and integration of financial technologies, Fintech companies can collaborate with other financial institutions. This can be done through partnerships, joint ventures and many other initiatives (Lee \& Shin, 2018). Several advantages of cooperation between smaller Fintech companies with larger financial institutions would include better propositions value, cost savings, gaining of new competitive advantages, and better solutions when confronting threats from technology-driven firms (Acar \& Çitak, 2019; Hornuf et al., 2020; Iman, 2019). Additionally, collaboration among companies can improve Fintech market reach and promote Fintech services by Fintech consumers (Teja, 2017).

Sloboda \& Demianyk (2020) point up to several critical steps for effective cooperation between financial institutions and fintech companies that would include:

(1) Ensure leadership buy-in. 
(2) Establish explicit business objectives.

(3) Align expectations at the start.

(4) Gain access to incumbent firms' infrastructure.

(5) Ensure cultural compatibility.

(6) Define ownership of intellectual property.

(7) Develop and monitor indicators.

(8) Seek timely dialogue with all stakeholders.

(9) Set up continuous monitoring.

(10)Develop contingency plans to protect against partnership failure.

\subsection{Nurtured the Fintech Talents}

The development of Fintech talents should be nurtured as earlier as possible. To meet the demand for Fintech talents, educational institutions like colleges and universities should introduce new and comprehensive Fintech courses to new students and update the existing curriculum by embedding more technological knowledge into it (Alshater \& Othman, 2020; Kavuri \& Milne, 2018; Mei et al., 2018). Jamil \& Abu Seman (2019) also suggest using extracurricular events to enhance Fintech knowledge through hackathons, mentorship programs, independent course offerings for specific skill enhancement, conferences, and both privately funded and publicly funded events. They also added how the government and policy interventions could help overcome Fintech talent shortage through financial support for new graduate startup networks, streamlined immigration processes meant to attract foreign talent, and various policies that show how local, national, and regional governments can attract foreign talent could support the Fintech sector. Existing companies and financial institutions need to actively support their employees' career development in Fintech when transitioning into the fintech sector (Crosman, 2018). It can be done through training programs to fill the knowledge gap (Oeshwik \& Benazir, 2020).

\section{Conclusion}

With the current emerging technology trends, Fintech innovations will continue to grow in the coming future. Acknowledging the fact, this paper was set out to address the Fintech conceptualization and its governing issues based upon reviewing the Fintech works of literature specifically from the context of the developing county, Malaysia. This study suggests that the Fintech concept is manifested from the definition, its applications to the advancement of this innovation. Fintech is defined as a new financial technology that utilizes the technology for any financial tasks and responsibilities improvement. Besides, the economic dimension of Fintech, inclusive of Crowdfunding, Mobile Payment, Robo-Advisers, Insuretch and Blockchain, are amongst the most common identified Fintech application.

Finding from this paper also highlights the growth of the global Fintech, emphasizing the Malaysian Fintech ecosystem. It is shown that the Fintech development in the country is quite encouraging. The emergence of Fintech in Malaysia has altered the country's financial sector landscape. Although Fintech is considered a new phenomenon in Malaysia, yet the rapid pace of growth is viewed from the areas of Peer-to-peer (P2P) financing and equity crowdfunding (ECF), Mobile wallet, Initial Coins Offerings (ICOs)/ Crypto Assets and banking sectors. The 
result shed some light on Fintech research areas by identifying the governing issues surrounding fintech implementation. These governing risks and challenges that hinder the effective deployment of Fintech in Malaysia include security issues, regulatory issues, technology integration and lack of skills and knowledge.

Additionally, learning how to overcome these challenges could be a matter of life-or-death situation for these companies. Hence among the proposed recommendations to tackle the governing issues of Fintech include the players need to be more cautious when handling new fintech innovations. For instance, strengthening securities and improving internal controls can help protect sensitive data from being used irresponsibly. Besides, proper regulations can help nurture the steady development of Fintech within a controlled environment. While competition is important to drive innovation, cooperation between companies, consumers, and governmental bodies can provide tremendous benefits and help produce better facilities and workforce to handle the fintech wave. The collaboration with the Financial Institution and nurtured the Fintech talents are also worth further consideration.

This paper contributes to Fintech and IS research by emphasizing the Fintech conceptualization and evolution from the theoretical perspective in terms of its concept, system development over time, and challenges Fintech players face. From a practical standpoint, the contribution in the form of recommendation on how Fintech application could be utilized optimally by the fintech companies would positively impact the Malaysia ecosystem and contribute to the national agenda.

\section{Acknowledgement}

The research described in this paper is supported by the Accounting Research Institute, Universiti Teknologi MARA, Shah Alam, Selangor, Malaysia, under the research grant 600-RMC/ARI 5/3(026/2020).

\section{References}

Ab Razak, M. I., Mohd Dali, N. A., Dhillon, G., \& Manaf, A. W. A. (2020). Fintech In Malaysia: An Appraisal to the Need of Shariah-Compliant Regulation. Pertanika Journal of Social Science and Humanities, 28, 3223-3233. https://doi.org/10.47836/pjssh.28.4.40

Acar, O., \& Çitak, Y. E. (2019). Fintech Integration Process Suggestion for Banks. Procedia Computer Science, 158, 971-978. https://doi.org/10.1016/j.procs.2019.09.138

Agrawal, R., Paprzycki, M., \& Neha, G. (2020). Big Data, IoT, and Machine Learning: Tools and Applications (Internet of Everything (IoE) (1st ed.). CRC Press.

Ahn, K., \& Cho, J. (2019). Major concerns of FinTech (Financial Technology) services in the Korean market. Journal of Business \& Retail Management Research, 14(1), 123-134.

Aktar, M. A., Alam, M. M., \& Al-Amin, A. Q. (2021). Global economic crisis, energy use, CO2 emissions, and policy roadmap amid COVID-19. Sustainable Production and Consumption, 26, 770-781. https://doi.org/10.1016/j.spc.2020.12.029

Alam, N., Gupta, L., \& Zameni, A. (2019). Fintech and Islamic finance: Digitalization, 
development and disruption. In Fintech and Islamic Finance: Digitalization, Development and Disruption. https://doi.org/10.1007/978-3-030-24666-2

Alliance for Financial Inclusion. (2018). Sochi Accord: Fintech for Financial Inclusion. p. 4.

Alshater, M. M., \& Othman, A. H. A. (2020). Financial Technology Developments and their Effect on Islamic Finance Education. Journal of King Abdulaziz University, Islamic Economics, 33(3), 187-161. https://doi.org/10.4197/Islec.33-3.9

Alwi, S. (2021). Fintech As Financial Inclusion: Factors Affecting Behavioral Intention to Accept Mobile E-Wallet During Covid-19 Outbreak. Turkish Journal of Computer and Mathematics Education (TURCOMAT), 12(7), 2130-2141.

Arjunwadkar, P. Y. (2018). FinTech: The Technology Driving Disruption in the Financial Services Industry. Auerbach Publications.

Arner, D., Barberis, J., \& Buckley, R. (2017). FinTech and RegTech in a Nutshell, and the Future in a Sandbox. CFA Institute Research Foundation.

Arner, D. W., Barberis, J., \& Buckley, R. P. (2017). FinTech, regTech, and the reconceptualization of financial regulation. Northwestern Journal of International Law and Business, 37(3), 373-415.

Arner, D. W., Barberis, J. N., \& Buckley, R. P. (2015). The Evolution of Fintech: A New Post-Crisis Paradigm? SSRN Electronic Journal. https://doi.org/10.2139/ssrn.2676553

Arslanian, H., \& Fischer, F. (2019). The Future of Finance: The Impact of FinTech, AI, and Crypto on Financial Services. Palgrave Macmillan.

Baber, H. (2020). Impact of FinTech on customer retention in Islamic banks of Malaysia. International Journal of Business and Systems Research, 14, 217.

https://doi.org/10.1504/IJBSR.2020.10027614

Bank Negara Malaysia. (2014). Statement on Bitcoin. [Online] Available:

https://www.bnm.gov.my/-/statement-on-bitcoin

Bank Negara Malaysia. (2016). Financial Technology Regulatory Sandbox Framework. Central Bank of Malaysia, October, 2-14. [Online] Available:

http://www.bnm.gov.my/index.php?ch=57\&pg=137\&ac=533\&bb=file

Blakstad, S., \& Allen, R. (2018). FinTech Revolution: Universal Inclusion in the New Financial Ecosystem. In Palgrave Macmillan. https://doi.org/10.1007/978-3-319-76014-8

Bollaert, H., Lopez-de-Silanes, F., \& Schwienbacher, A. (2021). Fintech and access to finance. Journal of Corporate Finance, 68, 101941.

https://doi.org/https://doi.org/10.1016/j.jcorpfin.2021.101941

Broeders, D., \& Prenio, J. (2018). FSI Insights: Innovative technology in financial supervision. FSI Insights on Policy Implementation, July(9), 29.

Buckley, R., Arner, D., \& Barberis, J. (2016). The Evolution of Fintech: A New Post-Crisis 


\section{Macrothink}

Business and Economic Research ISSN 2162-4860 2021, Vol. 11, No. 3

Paradigm? Georgetown Journal of International Law, 47, 1271-1319.

https://doi.org/10.2139/ssrn.2676553

Cham, T. H., Low, S. C., Seong, L., Khin, A., \& Ling, R. (2018). Preliminary Study on Consumer Attitude towards FinTech Products and Services in Malaysia. International Journal of Engineering \& Technology, 7, 166-169.

https://doi.org/10.14419/ijet.v7i2.29.13310

Chan, K. H., Ng, T. H., \& Ng, H. (2020). Are Malaysians Ready for the Cashless Society? Evidence from Malaysia's Undergraduates. Global Business and Management Research: An International Journal, 12, 78-88.

Chang, V., Baudier, P., Zhang, H., Xu, Q., Zhang, J., \& Arami, M. (2020). How blockchain can impact financial services - The overview, challenges and recommendations from expert interviewees. Technological Forecasting and Social Change, 158(May), 120166.

https://doi.org/10.1016/j.techfore.2020.120166

Cheah, C. M., Teo, A. C., Sim, J. J., Oon, K. H., \& Tan, B. I. (2011). Factors Affecting Malaysian Mobile Banking Adoption: An Empirical Analysis. International Journal of Network and Mobile Technologies, 2(3), 149-160. http://ijnmt.com/

Chiu, I. H. Y. (2017). A new era in fintech payment innovations? A perspective from the institutions and regulation of payment systems. Law, Innovation and Technology, 9(2).

https://doi.org/10.1080/17579961.2017.1377912

Chong, T.-P., William Choo, K.-S., Yip, Y.-S., Chan, P.-Y., Julian Teh, H.-L., \& Ng, S.-S. (2019). An Adoption of Fintech Service in Malaysia. South East Asia Journal of Contemporary Business, Economics and Law, 18(5), 73-92.

Chuang, L.-M., Liu, C.-C., \& Kao, H.-K. (2016). The Adoption of Fintech Service: TAM perspective. International Journal of Management and Administrative Sciences, 3(07), 1-15. [Online] Available: http://www.ijmas.orgwww.ijmas.org

Crosman, P. (2018). How artificial intelligence is reshaping jobs in banking. American Banker, 183(88), 1-3. [Online] Available:

https://web.a.ebscohost.com/ehost/detail/detail?vid=0\&sid=3ad3135e-dbaf-4ff5-abf0-8d7849 afb0d3\%40sdc-v-sessmgr06\&bdata=JnNpdGU9ZWhvc3QtbGl2ZQ\%3D\%3D\#db=bth\&AN= 129468404

Das, S. R. (2019). The future of Fintech. Financial Management, 48(4), 981-1007.

https://doi.org/10.1111/fima.12297

Degerli, K. (2019). Regulatory Challenges and Solutions for Fintech in Turkey. Procedia Computer Science, 158, 929-937. https://doi.org/10.1016/j.procs.2019.09.133

Deloitte. (2020). Fintech: On the brink of further disruption (Issue December).

Desai, F. (2015). The Evolution Of Fintech. Forbes. [Online] Available:

https://www.forbes.com/sites/falgunidesai/2015/12/13/the-evolution-of-fintech/\#165d3fc37175 


\section{Macrothink}

Business and Economic Research ISSN 2162-4860 2021, Vol. 11, No. 3

Deshpande, A. (2020). AI/ML applications and the potential transformation of Fintech and Finserv sectors. 2020 13th CMI Conference on Cybersecurity and Privacy (CMI) - Digital Transformation - Potentials and Challenges(51275). pp. 1-6.

https://doi.org/10.1109/CMI51275.2020.9322734

Diniyya, A. A., Aulia, M., \& Wahyudi, R. (2021). Financial Technology Regulation in Malaysia and Indonesia: A Comparative Study. Ihtifaz: Journal of Islamic Economics, Finance, and Banking, 3(2), 67-87.

Di Pietro, R., Raponi, S., Caprolu, M., \& Cresci, S. (2021). New Dimensions of Information Warfare. In Advances in Information Security (Vol. 84). Springer.

https://doi.org/10.1007/978-3-030-60618-3_1

Dutta, S., Lanvin, B., Rossini, C., \& Bratt, M. (2019). The Network Readiness Index 2019: Towards a future-ready society.

FINTECH Circle Institute. (2020). Fintech Trends 2020.

Fintech News Malaysia (2021), Fintech Malaysia Report 2021 - Fintech Reaches an Inflection Point in Malaysia. [Online] Available:

https://fintechnews.my/27070/malaysia/fintech-malaysia-report-2021/

Fintech News Malaysia. (2019). Malaysia Fintech Report 2019.

Fong, V. (2020). Malaysia to Spend RM 1.2 Billion Promoting E-Wallets in 2020. Fintech News Malaysia. [Online] Available:

https://fintechnews.my/23971/e-wallets-malaysia/e-wallet-malaysia-pejana/

Gai, K., Qiu, M., \& Sun, X. (2018). A survey on FinTech. Journal of Network and Computer Applications, 103, 262-273. https://doi.org/10.1016/j.jnca.2017.10.011

Gai, K., Qiu, M., Sun, X., \& Zhao, H. (2017). Security and Privacy Issues: A Survey on FinTech BT - Smart Computing and Communication. Springer International Publishing. pp. 236-247.

Gupta, P., \& Tham, T. M. (2019). Fintech: The New DNA of Financial Services. Walter de Gruyter.

Hasan, R., Hassan, M. K., \& Aliyu, S. (2020). Fintech and Islamic Finance: Literature Review and Research Agenda. International Journal of Islamic Economics and Finance (IJIEF), 3(1), 75-94. https://doi.org/10.18196/ijief.2122

Hassan, M. K., Rabbani, M. R., \& Mahmood, M. A. (2020). Challenges for the islamic finance and banking in post COVID era and the role of Fintech. Journal of Economic Cooperation and Development, 41(3), 93-116.

Hernández, E., Öztürk, M., Sittón, I., \& Rodríguez, S. (2019). Data protection on fintech platforms. Communications in Computer and Information Science, 1047, 223-233. https://doi.org/10.1007/978-3-030-24299-2_19 


\section{Macrothink}

Business and Economic Research ISSN 2162-4860 2021, Vol. 11, No. 3

Hornuf, L., Klus, M. F., Lohwasser, T. S., \& Schwienbacher, A. (2020). How do banks interact with fintech startups? Small Business Economics.

https://doi.org/10.1007/s11187-020-00359-3

Hui, H., Manaf, A. W., \& Shakri, A. (2019). Fintech and the Transformation of the Islamic Finance Regulatory Framework in Malaysia. pp. 211-222.

https://doi.org/10.1108/978-1-78973-545-120191018

Iman, N. (2019). Traditional banks against fintech startups: A field investigation of a regional bank in Indonesia. Banks and Bank Systems, 14(3), 20-33.

https://doi.org/10.21511/bbs.14(3).2019.03

Iman, N. (2020). The rise and rise of financial technology: The good, the bad, and the verdict. Cogent Business and Management, 7(1). https://doi.org/10.1080/23311975.2020.1725309

Imerman, M. B., \& Fabozzi, F. J. (2020). Cashing in on innovation: a taxonomy of FinTech. Journal of Asset Management, 21(3), 167-177. https://doi.org/10.1057/s41260-020-00163-4

International Monetary Fund Report. (2020). Malaysia: A Flourishing Fintech Ecosystem. [Online] Available:

https://www.imf.org/en/News/Articles/2020/02/27/na022820-malaysia-a-flourishing-fintechecosystem

Jackson, J., Weiss, M., Schwarzenberg, A., Nelson, R., Sutter, K., \& Sutherland, M. (2021). Global Economic Effects of COVID-19.

Jagtiani, J., \& John, K. (2018). Fintech: The Impact on Consumers and Regulatory Responses. Journal of Economics and Business, 100, 1-6. https://doi.org/10.1016/j.jeconbus.2018.11.002

Jamil, N. N., \& Abu Seman, J. (2019). The Impact of Fintech On The Sustainability Of Islamic Accounting And Finance Education In Malaysia. Journal of Islamic, Social, Economics and Development (JISED), 4(17), 74-88. www.jised.com

Kang, J. (2018). Mobile payment in Fintech environment: trends, security challenges, and services. Human-Centric Computing and Information Sciences, 8.

https://doi.org/10.1186/s13673-018-0155-4

Kavuri, A., \& Milne, A. K. L. (2018). Fintech and the Future of Financial Services: What are the Research Gaps? SSRN Electronic Journal. https://doi.org/10.2139/ssrn.3215849

Kijkasiwat, P. (2021). Opportunities and challenges for Fintech Startups: The case study of Thailand. ABAC Journal, 41(2), 41-60.

Knewtson, H. S., \& Rosenbaum, Z. A. (2020). Toward understanding FinTech and its industry. Managerial Finance, 46(8), 1043-1060. https://doi.org/10.1108/MF-01-2020-0024

Knight, E., \& Wójcik, D. (2020). FinTech, economy and space: Introduction to the special issue. Environment and Planning A, 52(8), 1490-1497.

https://doi.org/10.1177/0308518X20946334 


\section{Macrothink}

Business and Economic Research ISSN 2162-4860 2021, Vol. 11, No. 3

Kulkarni, D., \& Lakhe, P. (2020). FinTech Regulations: Need, Superpowers and Bibliometric Analysis.

Lee, I., \& Shin, Y. J. (2018). Fintech: Ecosystem, business models, investment decisions, and challenges. Business Horizons, 61(1), 35-46. https://doi.org/10.1016/j.bushor.2017.09.003

Li, K., Kim, D. J., Lang, K. R., Kauffman, R. J., \& Naldi, M. (2020). How should we understand the digital economy in Asia? Critical assessment and research agenda. Electronic Commerce Research and Applications, 44. https://doi.org/10.1016/j.elerap.2020.101004

Malaysia Digital Economy Corporation. (2020). Launch of the Fintech Booster program [Press release]. pp. 2.

Mansour, H. (2021). How successful countries are in promoting digital transactions during COVID-19. Journal of Economic Studies, ahead-of-p.

https://doi.org/10.1108/JES-10-2020-0489

Mehrban, S., Nadeem, M. W., Hussain, M., Ahmed, M. M., Hakeem, O., Saqib, S., Kiah, M. L. M., Abbas, F., Hassan, M., \& Khan, M. A. (2020). Towards Secure FinTech: A Survey, Taxonomy, and Open Research Challenges. IEEE Access, 8, 23391-23406.

https://doi.org/10.1109/ACCESS.2020.2970430

Mei, S., Peiguang, L., \& Xiushan, N. (2018). Research on fintech industry development and talent training status. 13th International Conference on Computer Science and Education, ICCSE 2018, Iccse. pp. 384-387. https://doi.org/10.1109/ICCSE.2018.8468796

Micheler, E., \& Whaley, A. (2020). Regulatory Technology: Replacing Law with Computer Code. European Business Organization Law Review, 21(2), 349-377.

https://doi.org/10.1007/s40804-019-00151-1

Miskam, S., Mohd Shahwahid, F., \& Sholehuddin, N. (2018). Catching the Fintech Wave in Islamic Finance: Regulatory Approach for Malaysia. 4th Muzakarah Fiqh \& International Fiqh Conference (MFIFC 2018). pp. 223-235.

Mohamed, H. (2020). Beyond Fintech. In Beyond Fintech. https://doi.org/10.1142/11885

Mohamed, H., \& Ali, H. (2019). Blockchain, Fintech, and Islamic Finance. Building the Future in the New Islamic Digital Economy. Walter de Gruyter.

Moşteanu, N. R. (2020). Challenges for organizational structure and design as a result of digitalization and cybersecurity. The Business and Management Review, 11(1), 278-286.

Muthaiyah, S., \& Zaw, T. (2020). Digital know-how and FinTech readiness. pp. 1-4. https://doi.org/10.1201/9780367814557-01

Ng, A. W., \& Kwok, B. K. B. (2017). Emergence of Fintech and cybersecurity in a global financial centre: Strategic approach by a regulator. Journal of Financial Regulation and Compliance, 25(4), 422-434. https://doi.org/10.1108/JFRC-01-2017-0013

Nicoletti, B. (2017). The Future of FinTech: Integrating Finance and Technology in 
Financial Services (1st ed.). Palgrave Macmillan.

O’Hanlon, S., Chishti, S., Bradley, B., Jockle, J., \& Patrick, D. (2020). FinTech For Dummies. John Wiley \& Sons.

Oeshwik, A., \& Benazir, R. (2020). Employees of commercial banks learning to unlearn: a case study on the impact of electronic banking in the commercial banks of Bangladesh. International Journal of Business and Technopreneurship, 10(1), 31-50.

Omarova, S. T. (2020). Technology v Technocracy: Fintech as a Regulatory Challenge. Journal of Financial Regulation, 6(1), 75-124. https://doi.org/10.1093/jfr/fjaa004

Ooi, C. K., Tang, K. L., \& Chong, J. B. (2020). Perceived Risk Factors Affect Intention To Use FinTech. Journal of Accounting and Finance in Emerging Economies, 6(2), 453-463. https://doi.org/10.26710/jafee.v6i2.1101

Peterson, A. (2014). eBay asks 145 million users to change passwords after data breach. The Washington Post. [Online] Available:

https://www.washingtonpost.com/news/the-switch/wp/2014/05/21/ebay-asks-145-million-use rs-to-change-passwords-after-data-breach/

Pillai, S. (2018). Does Facebook's data breach spell the beginning of the end for digital advertising? The Edge Markets. [Online] Available:

https://www.theedgemarkets.com/article/does-facebooks-data-breach-spell-beginning-end-dig ital-advertising

Puschmann, T. (2017). Fintech. Business \& Information Systems Engineering, 59. https://doi.org/10.1007/s12599-017-0464-6

Putritama, A. (2019). The Mobile Payment Fintech Continuance Usage Intention in Indonesia. Jurnal Economia, 15(2), 243-258. https://doi.org/10.21831/economia.v15i2.26403

PwC. (2016). Security challenges in the evolving fintech landscape. [Online] Available:

https://www.pwc.in/assets/pdfs/consulting/cyber-security/banking/security-challenges-in-theevolving-fintech-landscape.pdf

PwC. (2019). Global Fintech Report 2019.

Qi, B. Y., \& Xiao, J. (2018). Fintech: AI powers financial services to improve people's lives. Communications of the ACM, 61(11), 65-69. https://doi.org/10.1145/3239550

Rabbani, M. R., Khan, S., \& Thalassinos, E. I. (2020). FinTech, Blockchain and Islamic finance: An extensive literature review. International Journal of Economics and Business Administration, 8(2), 65-86. https://doi.org/10.35808/ijeba/444

Rabin, K. (2020). Malaysia is the latest country to hop on the fintech trend. Finextra. [Online] Available: https://www.finextra.com/blogposting/18505/malaysia-is-the-latest-country-to-hop -on-the-fintech-trend

Razzaque, A., \& Hamdan, A. (2020). Role of Financial Technology FinTech: A Survey. In 
Proceedings of the International Conference on Artificial Intelligence and Computer Vision (AICV2020). pp. 112-117. Springer. https://doi.org/10.1007/978-3-030-44289-7_11

Rupeika-Apoga, R., \& Thalassinos, E. I. (2020). Ideas for a regulatory definition of FinTech. International Journal of Economics and Business Administration, 8(2), 136-154.

https://doi.org/10.35808/ijeba/448

Ryu, H.-S. (2018). What makes users willing or hesitant to use Fintech?: the moderating effect of user type. Industrial Management \& Data Systems, 118(3), 541-569.

https://doi.org/10.1108/IMDS-07-2017-0325

Ryu, H. S. (2018). Understanding benefit and risk framework of fintech adoption: comparison of early adopters and late adopters. Proceedings of the 51st Hawaii International Conference on System Sciences. [Online] Available:

http://hdl.handle.net/10125/50374

Ryu, H. S., \& Ko, K. S. (2020). Sustainable development of Fintech: Focused on uncertainty and perceived quality issues. Sustainability (Switzerland), 12(18).

https://doi.org/10.3390/su12187669

Schueffel, P. (2016). Taming the Beast: A Scientific Definition of Fintech. Journal of Innovation Management, 4(4), 32-54. https://doi.org/10.24840/2183-0606_004.004_0004

Schueffel, P. (2017). The Concise Fintech Compendium. School of Management Fribourg.

Shaikh, I. M., Qureshi, M. A., Noordin, K., Shaikh, J. M., Khan, A., \& Shahbaz, M. S. (2020). Acceptance of Islamic financial technology (FinTech) banking services by Malaysian users: an extension of technology acceptance model. Foresight, 22(3), 367-383.

https://doi.org/10.1108/FS-12-2019-0105

Sloboda, L. Y., \& Demianyk, O. M. (2020). Prospects and Risks of the Fintech Initiatives in a Global Banking Industry. The Problems of Economy, 1(43), 275-282.

https://doi.org/10.32983/2222-0712-2020-1-275-282

Stewart, H., \& Jürjens, J. (2018). Data security and consumer trust in FinTech innovation in Germany. Information and Computer Security, 26(1), 109-128.

https://doi.org/10.1108/ICS-06-2017-0039

Sung, A., Leong, K., Sironi, P., O’Reilly, T., \& McMillan, A. (2019). An exploratory study of the FinTech (Financial Technology) education and retraining in UK. Journal of Work-Applied Management, 11(2), 187-198. https://doi.org/10.1108/jwam-06-2019-0020

Suryono, R. R., Budi, I., \& Purwandari, B. (2020). Challenges and trends of financial technology (Fintech): A systematic literature review. Information (Switzerland), 11(12), 1-20. https://doi.org/10.3390/info11120590

Szakiel, P. (2018). What Is Fintech: A Beginner's Guide to Financial Technology in 2019. G2. [Online] Available: https://www.g2.com/articles/fintech

Teja, A. (2017). Indonesian Fintech Business: New Innovations or Foster and Collaborate in 


\section{Macrothink}

Business and Economic Research ISSN 2162-4860 2021, Vol. 11, No. 3

Business Ecosystems? The Asian Journal of Technology Management (AJTM), 10(1), 10-18. https://doi.org/10.12695/ajtm.2017.10.1.2

University of Malaya Malaysian Centre of Regulatory Studies. (2018). Malaysian Blockchain Regulatory Report.

Varshney, S., Munjal, D., Bhattacharya, O., Saboo, S., \& Aggarwal, N. (2020). Big data privacy breach prevention strategies. Proceedings - 2020 IEEE International Symposium on Sustainable Energy, Signal Processing and Cyber Security, ISSSC 2020. https://doi.org/10.1109/iSSSC50941.2020.9358878

Vijai, C. (2019). Fintech in India - Opportunities and Challenges. SAARJ Journal on Banking \& Insurance Research (SJBIR), 8(1), 13.

https://papers.ssrn.com/sol3/papers.cfm?abstract_id=3354094

Wang, Y., Xiuping, S., \& Zhang, Q. (2021). Can Fintech improve the efficiency of commercial banks? -An analysis based on big data. Research in International Business and Finance, 55, 101338. https://doi.org/https://doi.org/10.1016/j.ribaf.2020.101338

World Bank and World Economic Forum. (2020). The Global Covid-19 FinTech Market Rapid Assessment Study.

Yusof, A. (2021, April 14). Luno Malaysia manages over RM1bil DAUM. New Straits Times. [Online] Available: https://www.nst.com.my/business/2021/04/682203/luno-malaysia-manage s-over-rm1bil-daum

Zavolokina, L., Dolata, M., \& Schwabe, G. (2016, December). FinTech - What's in a Name? Proceedings in International Conference on Information Systems.

Zhang-Zhang, Y., Rohlfer, S., \& Rajasekera, J. (2020). An eco-systematic view of cross-sector Fintech: The case of Alibaba and Tencent. Sustainability (Switzerland), 12(21), 1-25. https://doi.org/10.3390/su12218907

Zigurat Global Institute of Technology. (2020). Evolution of Fintech - Innovation \& Technology Blog. [Online] Available:

https://www.e-zigurat.com/innovation-school/blog/evolution-of-fintech/

\section{Copyright Disclaimer}

Copyright for this article is retained by the author(s), with first publication rights granted to the journal.

This is an open-access article distributed under the terms and conditions of the Creative Commons Attribution license (http://creativecommons.org/licenses/by/4.0/). 